\title{
EFFECTS OF THE AMOUNT OF STARCH AND THE HOLDING TIME ON THE SYNTHESIS OF SiC-TiC COMPOSITE POWDERS
}

\author{
\#JILIN HU, YU CAO, XIN LIU, LING ZHU, JING LI, JIN WEN, YANGXI PENG, ZHANJUN CHEN \\ Hunan Provincial Key Laboratory of Fine Ceramics and Powder Materials, School of Materials and Environmental \\ Engineering, Hunan University of Humanities, Science and Technology, Loudi 417000, China \\ \#E-mail: hujilin@126.com
}

Submitted September 3, 2021; accepted October 22, 2021

\begin{abstract}
Keywords: Influence, Carbothermal reduction method, Silicon carbide, Titanium carbide, Preparation
$\mathrm{SiC}-\mathrm{TiC}$ composite powders were synthesised through carbothermal reduction under an argon atmosphere by using silica sol, starch, and $\mathrm{TiO}_{2}$ as the raw materials. The influences of the starch dosage and holding time on the synthesis of $\mathrm{SiC}-\mathrm{TiC}$ composite powder are discussed in detail. The samples were characterised using an X-ray diffractometer (XRD), an integrated thermal analyser (TG-DTA), a scanning electron microscope (SEM), and an energy spectrometer (EDS). The results showed that the $\mathrm{SiC}-\mathrm{TiC}$ composite powders were completely synthesised after holding at $1550{ }^{\circ} \mathrm{C}$ for $3 \mathrm{~h}$ when the amount of excess starch was $5 \mathrm{wt} . \%$ and after holding at $1550^{\circ} \mathrm{C}$ for $2 \mathrm{~h}$ when the amount of excess starch was $10-20 \mathrm{wt} . \%$. The morphological characteristics of the powder samples with $5-15 \mathrm{wt}$. \% excess starch calcined at $1550{ }^{\circ} \mathrm{C}$ for $2 \mathrm{~h}$ were mainly flake particles, spherical particles, irregularly shaped particles and elongated whiskers. Conversely, no whiskers were found in the powder samples calcined at $1550^{\circ} \mathrm{C}$ for $2 \mathrm{~h}$ when the amount of excess starch was $20 \mathrm{wt} . \%$.
\end{abstract}

\section{INTRODUCTION}

Silicon carbide $(\mathrm{SiC})$ has a series of advantages, such as high-temperature strength, high hardness, high thermal conductivity, good chemical stability, and excellent oxidation resistance. It is widely used in many fields, such as the chemical industry, the textile industry, in machinery, the military industry, and in energy, and its application prospects vary broadly [1-3]. Nevertheless, the room-temperature strength and fracture toughness of $\mathrm{SiC}$ are low, thereby limiting its application range [4]. Titanium carbide (TiC) is an important engineering material, with a high hardness (28 - $33 \mathrm{GPa}$ ), high melting point $\left(>3000{ }^{\circ} \mathrm{C}\right)$, good chemical stability, high electrical and thermal conductivities, high fracture toughness, and other excellent comprehensive performance parameters [5-7]. As such, a $\mathrm{SiC}$ and $\mathrm{TiC}$ composite can achieve the complementarity of the properties of the two materials, resulting in the enhanced performance of the $\mathrm{SiC}-\mathrm{TiC}$ composite, which can be applied to more fields [8]. SiC-TiC ceramic powders prepared by direct mechanical mixing have inhomogeneity in a mixed powder composition, which affects the microstructure and related properties of the $\mathrm{SiC}-\mathrm{TiC}$ composites to a certain extent. Therefore, high-quality $\mathrm{SiC}-\mathrm{TiC}$ ultrafine composite powders should be prepared with small particles, uniform mixing, and good dispersibility to meet material performance requirements.

Ultrafine carbide powders are commonly prepared using various methods, including carbothermal reduction [9-10], mechanical alloying [11], chemical vapour deposition [12], and combustion synthesis [13]. Carbothermal reduction is currently the most important preparation method used in industrial production because of its low-cost raw materials, simple preparation, and easy realisation of a uniform compound of powders. In our previous research, $\mathrm{SiC}-\mathrm{TiC}$ ultrafine composite powders were prepared through carbothermal reduction by selecting inorganic carbon sources, such as carbon black [14] and graphite [15]. As an organic carbon source, starch easily forms fine carbon particles during hightemperature carbonisation and decomposition in an argon atmosphere, which is conducive to the generation of an ultrafine carbide powder [16]. In other previous work [15], starch was chosen as the raw carbon source material, and the influence of different reaction temperatures on the phase composition, particle size distribution, and microstructure of $\mathrm{SiC}-\mathrm{TiC}$ composite powders was discussed. In the present study, we intend to focus on the effects of the amount of starch and the holding time on the phase composition and microstructure of $\mathrm{SiC}-\mathrm{TiC}$ composite powders synthesised using starch as a carbon source.

\section{EXPERIMENTAL \\ Processing}

Silica sol $\left(\mathrm{SiO}_{2}, 28\right.$ wt. \%, Hunan Changsha Water Glass Factory, Changsha, China), soluble starch $\left(\left(\mathrm{C}_{6} \mathrm{H}_{10} \mathrm{O}_{5}\right)\right.$ n, purity of $\geq 99.0 \%$, Hunan Xiangzhong Chemical Reagent Co., Ltd., Loudi, China), and $\mathrm{TiO}_{2}$ 
(purity of $\geq 99.0 \%, \mathrm{D}_{50}=1.70 \mu \mathrm{m}$, Shantou Guanghua Chemical Co., Ltd., Shantou, China) were used as the starting materials for the synthesis of the $\mathrm{SiC}-\mathrm{TiC}$ composite powders. The preparation of the $\mathrm{SiC}-\mathrm{TiC}$ composite powders is shown in Figure 1. The amounts of silica sol, starch, and $\mathrm{TiO}_{2}$ were adjusted to yield a TiC/SiC molar ratio of 7:3. The amounts of starch were designed to be in excess of 5 wt. $\%, 10$ wt. $\%, 15$ wt. $\%$, and 20 wt. $\%$ of the theoretical calculation. These raw materials were uniformly mixed in a planetary ball mill at a speed of $400 \mathrm{rev} \cdot \mathrm{min}^{-1}$ for $2 \mathrm{~h}$ by using $\mathrm{SiC}$ balls as the grinding body and anhydrous ethanol as the dispersing medium (the solid-to-liquid mass ratio was set to 1:2). The well-mixed starting materials were taken out and dried at $80{ }^{\circ} \mathrm{C}$ for $24 \mathrm{~h}$. After being ground, they were placed in a graphite crucible and in a high-temperature tubular electric furnace. The high-temperature synthesis reaction was carried out from room temperature to $1550{ }^{\circ} \mathrm{C}$ at a heating rate of $10{ }^{\circ} \mathrm{C} \cdot \mathrm{min}^{-1}$ in an argon atmosphere. The holding times at the desired temperature were 1,2 , and $3 \mathrm{~h}$. Subsequently, the furnace was cooled naturally to room temperature, and the $\mathrm{SiC}-\mathrm{TiC}$ composite powders were obtained.

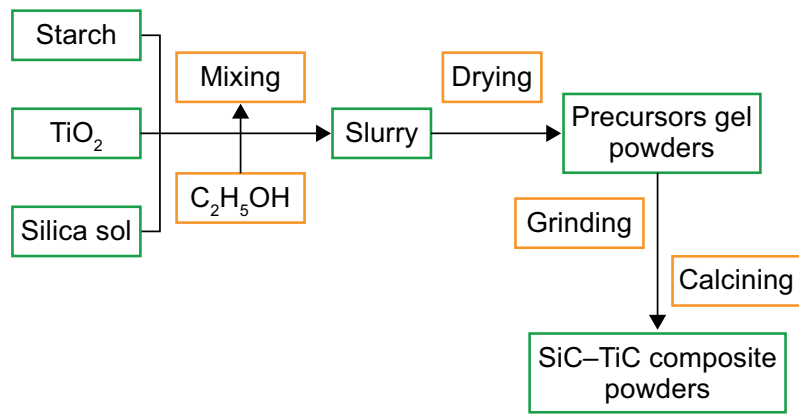

Figure 1. Preparation of the SiC-TiC composite powders.

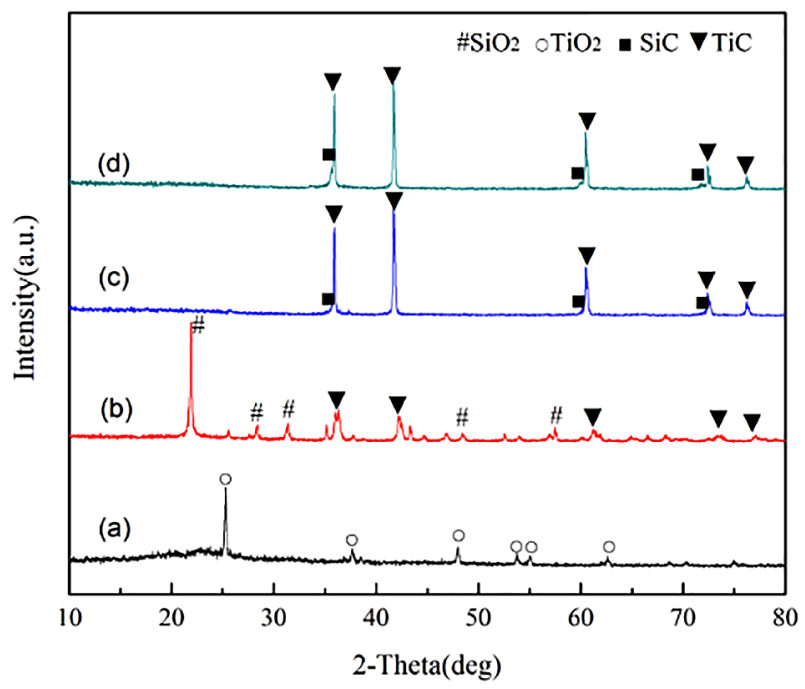

Figure 2. XRD patterns of the samples containing $5 \mathrm{wt} . \%$ excess of starch, dried at $80{ }^{\circ} \mathrm{C}$, and maintained at $1550{ }^{\circ} \mathrm{C}$ for different periods: a) $80^{\circ} \mathrm{C}$, b) $1550{ }^{\circ} \mathrm{C}+1 \mathrm{~h}$, c) $1550{ }^{\circ} \mathrm{C}+2 \mathrm{~h}$, d) $1550{ }^{\circ} \mathrm{C}+3 \mathrm{~h}$

\section{Characterisation}

The TG-DTA curve of a single starch was examined using a DTA-50 comprehensive thermal analyser (TG-DTA, DTA-50, Shimadzu Company, Japan). The masses of the samples before and after calcination were weighed with an electronic analytical balance (accurate to $0.1 \mathrm{mg}$ ), and the mass loss was calculated to evaluate the degree of the high-temperature synthesis. The phase composition of the powder samples dried at $80{ }^{\circ} \mathrm{C}$ and calcined at $1550{ }^{\circ} \mathrm{C}$ for different periods was analysed using an X-ray diffractometer (XRD, Y2000, Tongda Company, China). The morphological characteristics of the samples dried at $80{ }^{\circ} \mathrm{C}$ and calcined at $1550{ }^{\circ} \mathrm{C}$ for different periods were observed under a scanning electron microscope (SEM, Zeiss Sigma 500, Germany).

\section{RESULTS AND DISCUSSION}

Phase composition

Figure 2 shows the XRD patterns of the precursor powder dried at $80{ }^{\circ} \mathrm{C}$ and the powder calcined at $1550{ }^{\circ} \mathrm{C}$ for different periods with 5 wt. \% excess of starch. In Figure $2 \mathrm{a}$, the $\mathrm{TiO}_{2}$ diffraction peak is mainly present in the precursor mixed powder dried at $80^{\circ} \mathrm{C}$, but no $\mathrm{SiO}_{2}$ diffraction peak appears. These findings indicate that the $\mathrm{SiO}_{2}$ component in the silica sol is mainly present as an amorphous form in the precursor. Consistent with these results, our previous study [17] demonstrated that the $\mathrm{SiO}_{2}$ characteristic diffraction peak is still not found in the system after calcination at $1400{ }^{\circ} \mathrm{C}$ for $2 \mathrm{~h}$. When the holding time is for $1 \mathrm{~h}$ at $1550^{\circ} \mathrm{C}$, the diffraction peaks of $\mathrm{TiC}$ and $\mathrm{SiO}_{2}$ simultaneously appear in the synthesised product, as shown in Figure 2b, but the characteristic diffraction peaks of $\mathrm{SiC}$ are still not evident at this time. This finding illustrates that $\mathrm{TiC}$ forms in the system under this condition, but the $\mathrm{SiC}$ formation has not yet fully started. Notably, the diffraction peak of carbon is not found in Figure 2b, indicating that the elemental carbon produced by the decomposition of the starch raw materials at a high temperature mainly exists in an amorphous form in the system. Our previous study [17] has also shown that the elemental carbon formed through the decomposition of glucose at a high temperature is amorphous. Indeed, elemental carbon as the main product of the decomposition of organic carbon sources, such as starch and glucose, at high temperatures is amorphous. When the holding time is $2 \mathrm{~h}$, strong TiC diffraction peaks and relatively weak $\mathrm{SiC}$ diffraction peaks appear in the system, as illustrated in Figure 2c. Other impurity peaks are not obvious, indicating that the $\mathrm{TiC}$ synthesis is almost complete, but the $\mathrm{SiC}$ synthesis is not yet fully completed. After the holding time is extended to $3 \mathrm{~h}$, the TiC diffraction peak in the system does not change significantly, but the intensity of the $\mathrm{SiC}$ diffraction peak further enhances, and the peak shape sharpens, as presented in Figure 2d. In summary, when 
the amount of excess starch is $5 \mathrm{wt} . \%$, the $\mathrm{SiC}-\mathrm{TiC}$ composite powder is completely synthesised at $1550{ }^{\circ} \mathrm{C}$ for $3 \mathrm{~h}$ with starch as the carbon source. This observation is basically consistent with the analysis result of the mass loss in the subsequent synthesis.

Figure 3 shows the XRD patterns of the precursor powder dried at $80^{\circ} \mathrm{C}$ and the powder calcined at $1550{ }^{\circ} \mathrm{C}$ for different times with 10 wt. \% excess of starch. In Figure $3 \mathrm{a}$, the $\mathrm{TiO}_{2}$ diffraction peak is mainly present in the precursor mixed powder dried at $80{ }^{\circ} \mathrm{C}$, but no $\mathrm{SiO}_{2}$ diffraction peak forms. When the holding time is $1 \mathrm{~h}$ at $1550{ }^{\circ} \mathrm{C}$, the strong characteristic diffraction peaks of $\mathrm{TiC}$ and $\mathrm{SiO}_{2}$ appear at the same time, indicating that $\mathrm{TiC}$ is synthesised in the $\mathrm{SiC}-\mathrm{TiC}$ composite powder. In comparison with the peaks shown in Figure $2 \mathrm{c}$ and in addition to the sharp peak-shaped TiC diffraction peak presented in Figure 3c, strong $\mathrm{SiC}$ diffraction peaks appear in the synthesised product when the holding time at $1550{ }^{\circ} \mathrm{C}$ is $2 \mathrm{~h}$. At the same time, the characteristic diffraction peak of $\mathrm{SiO}_{2}$ disappears, while the other impurity peaks are not yet obvious, indicating that $\mathrm{TiC}$ and $\mathrm{SiC}$ are completely synthesised. Therefore, as the amount of starch in the system increases, the amount of elemental carbon produced by the decomposition of the starch at high temperatures also increases, thereby remarkably increasing the contact area between the $\mathrm{SiO}_{2}$ and $\mathrm{C}$ particles during the high-temperature synthesis. Furthermore, the formation of $\mathrm{SiC}$ between the raw materials of the reactants accelerates. The holding time is extended to $3 \mathrm{~h}$, and the diffraction peaks in the synthesised product do not change significantly. According to the review, a $\mathrm{SiC}-\mathrm{TiC}$ composite powder is completely produced at $1550{ }^{\circ} \mathrm{C}$ for $2 \mathrm{~h}$ when the amount of excess starch is 10 wt. $\%$.

Figure 4 shows the XRD patterns of the precursor powder dried at $80{ }^{\circ} \mathrm{C}$ and the powder calcined at

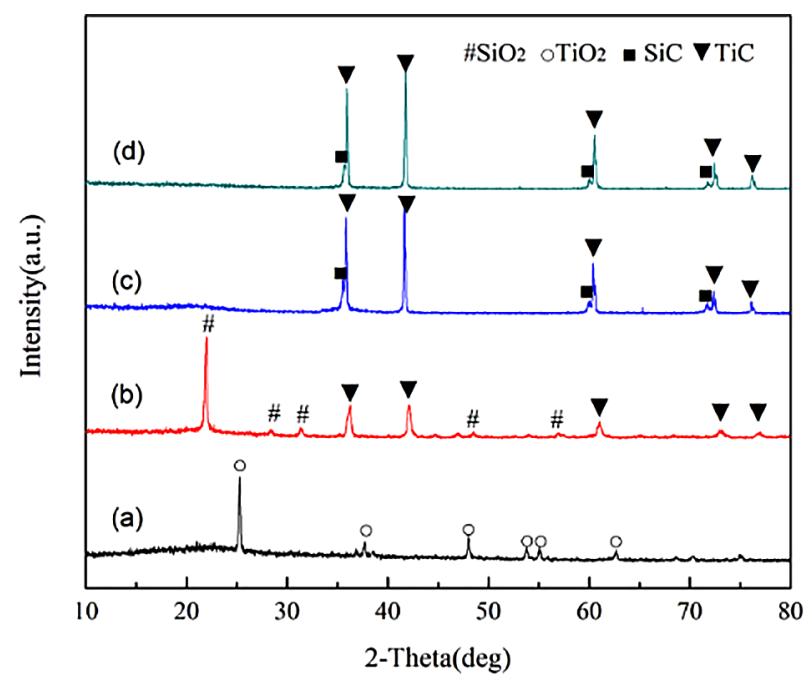

Figure 3. XRD patterns of the samples containing $10 \mathrm{wt} . \%$ excess of starch, dried at $80^{\circ} \mathrm{C}$, and maintained at $1550{ }^{\circ} \mathrm{C}$ for different periods: a) $80^{\circ} \mathrm{C}$, b) $1550{ }^{\circ} \mathrm{C}+1 \mathrm{~h}$, c) $1550{ }^{\circ} \mathrm{C}+2 \mathrm{~h}$, d) $1550{ }^{\circ} \mathrm{C}+3 \mathrm{~h}$.
$1550{ }^{\circ} \mathrm{C}$ for different periods with 15 wt. \% excess of starch. In comparison with the peaks shown in Figures 2 and 3, a strong TiC characteristic diffraction peak and a weak $\mathrm{SiC}$ characteristic diffraction peak are presented in Figure $4 b$, but no $\mathrm{SiO}_{2}$ diffraction peak is found. Therefore, as the amount of starch in the system further increases, the amount of elemental carbon generated at high temperatures increases; consequently, the contact area between the $\mathrm{SiO}_{2}$ and $\mathrm{C}$ particles increases during high-temperature synthesis, and the reaction time for the $\mathrm{SiC}$ formation shortens. The following analysis of the mass loss also indicates that the $\mathrm{SiC}-\mathrm{TiC}$ composite powder is relatively synthesised completely at $1550{ }^{\circ} \mathrm{C}$

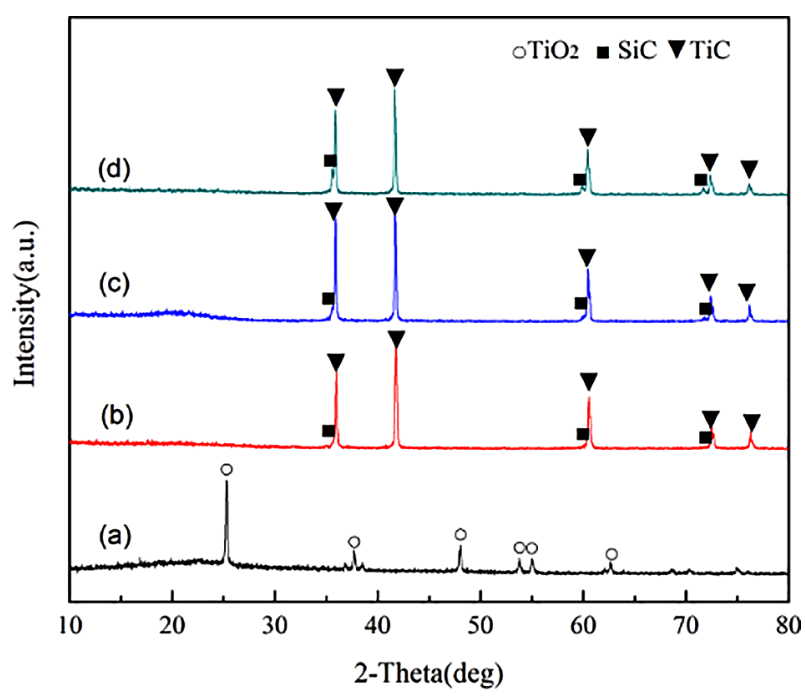

Figure 4. XRD patterns of the samples containing $15 \mathrm{wt} \%$ excess of starch, dried at $80^{\circ} \mathrm{C}$, and maintained at $1550{ }^{\circ} \mathrm{C}$ for different periods: a) $80{ }^{\circ} \mathrm{C}$, b) $1550{ }^{\circ} \mathrm{C}+1 \mathrm{~h}$, c) $1550{ }^{\circ} \mathrm{C}+2 \mathrm{~h}$, d) $1550{ }^{\circ} \mathrm{C}+3 \mathrm{~h}$.

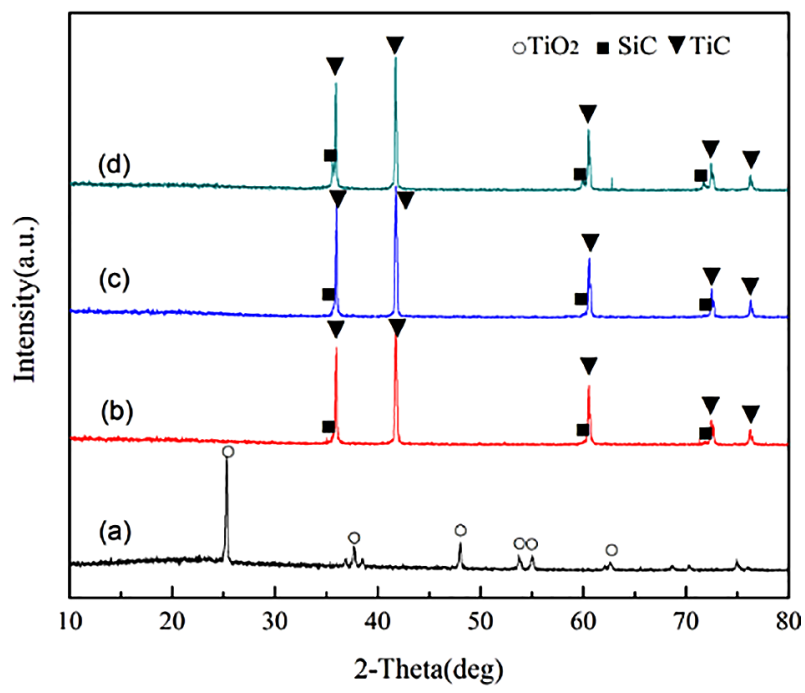

Figure 5. XRD patterns of the samples containing 20 wt. $\%$ excess of starch, dried at $80^{\circ} \mathrm{C}$, and maintained at $1550{ }^{\circ} \mathrm{C}$ for different periods: a) $80^{\circ} \mathrm{C}$, b) $1550^{\circ} \mathrm{C}+1 \mathrm{~h}$, c) $1550^{\circ} \mathrm{C}+2 \mathrm{~h}$, d) $1550{ }^{\circ} \mathrm{C}+3 \mathrm{~h}$. 
for $2 \mathrm{~h}$ with $15 \mathrm{wt} . \%$ excess of starch. Figure 5 illustrates the XRD patterns of the precursor powder dried at $80{ }^{\circ} \mathrm{C}$ and the powder calcined at $1550{ }^{\circ} \mathrm{C}$ for different periods with 20 wt. $\%$ excess of starch. The XRD patterns of the various phases in Figure 5 exhibit changes similar to those in Figure 4. This result demonstrates that the $\mathrm{SiC}-\mathrm{TiC}$ composite powders are completely synthesised at $1550{ }^{\circ} \mathrm{C}$ for $2 \mathrm{~h}$ in the presence of $20 \mathrm{wt} . \%$ excess of starch.

\section{Degree of the synthesis reaction}

Table 1 shows the mass loss during the synthesis reaction at $1550{ }^{\circ} \mathrm{C}$ for different holding times. It can be seen from Table 1 that when the amount of starch is the same, with the extension of the holding time, the mass loss of the synthesis reaction in the system increases, and the reaction process is obviously strengthened. When the amount of excess starch is $5 \mathrm{wt}$. \% and the holding time is $1 \mathrm{~h}$, the mass loss during the reaction is $67.9 \%$. When the holding time is $2 \mathrm{~h}$, the mass loss during the reaction increases to $80.0 \%$; when the holding time continues to increase to $3 \mathrm{~h}$, the mass loss only increases by $2.6 \%$.

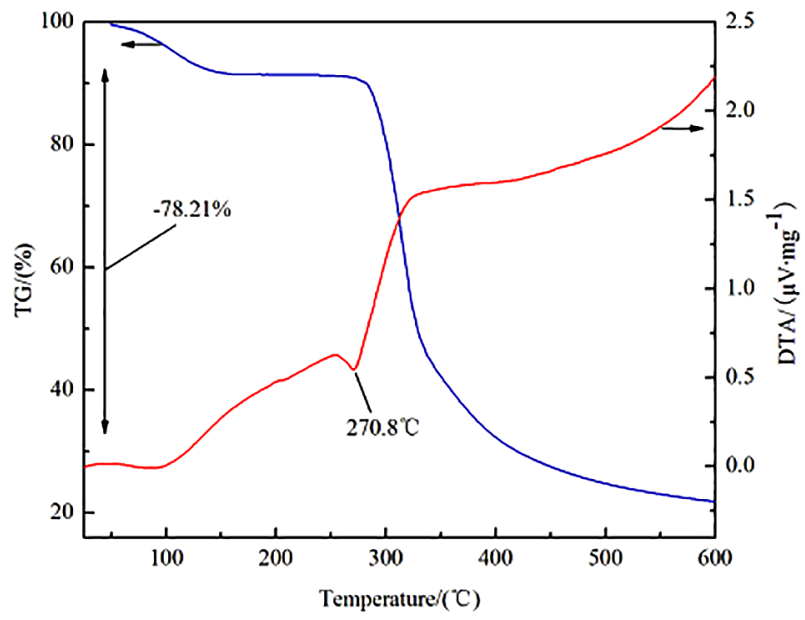

Figure 6. TG-DTA curve of a single starch raw material under an argon atmosphere.
When the amount of excess starch is $10 \mathrm{wt} . \%, 15 \mathrm{wt} . \%$, and 20 wt. \%, the mass loss of synthesis in the system shows similar changes under different holding time conditions. When the holding time is 2 and $3 \mathrm{~h}$, the mass loss of the synthesis in the system is, at most, as high as $80-85$ wt. \%. During the carbothermal reduction to synthesise the $\mathrm{SiC}-\mathrm{TiC}$ composite powder, the mass loss is higher because of the following: On the one hand, under an argon atmosphere, the TG-DTA curve of a single starch raw material (Figure 6) shows that the starch decomposes, resulting in a mass loss of up to $78.2 \%$. That is, it decomposes to form elemental carbon and gaseous $\mathrm{H}_{2} \mathrm{O}$ at low temperatures. At high temperatures, the starch continuously decomposes to produce a certain amount of gas-phase products, such as $\mathrm{CO}, \mathrm{CO}_{2}$, and $\mathrm{CxHy}$, which are discharged with the airflow, resulting in a quality loss [16]. On the other hand, the gaseous $\mathrm{SiO}$ as the intermediate product forms and escapes in the carbothermal reduction of $\mathrm{SiO}_{2}$ and carbon to produce the $\mathrm{SiC}$ powder, thereby causing a quality loss [18].

\section{Microstructure}

Figure 7 shows the SEM photographs of the precursor powder dried at $80{ }^{\circ} \mathrm{C}$ and the powder calcined at $1550{ }^{\circ} \mathrm{C}$ for different periods with $10 \mathrm{wt} . \%$ excess of starch. In Figure $7 \mathrm{a}$, the dried sample is mainly spherical and massive, and other loose raw material particles are stacked together. The powder samples prepared at $1550^{\circ} \mathrm{C}$ for $1 \mathrm{~h}$ is mainly composed of a certain amount of coarse flake particles and numerous small irregularly shaped particles; furthermore, agglomeration or adhesion occurs between the powder particles, as shown in Figure $7 \mathrm{~b}$. When the powder sample is kept at $1550{ }^{\circ} \mathrm{C}$ for $2 \mathrm{~h}$, its morphological characteristics change significantly. In addition to the flake particles and irregularly shaped particles (particle size of about $50-100 \mathrm{~nm}$ ), uniform and slender whiskers form (about $50-100 \mathrm{~nm}$ in diameter), and an overlap and entanglement exist between the whiskers, as shown in Figure 7c. In Figure 7d, when

Table 1. Mass loss in the synthesis of $\mathrm{SiC}-\mathrm{TiC}$ composite powders at $1550{ }^{\circ} \mathrm{C}$ for different periods with various amounts of starch

\begin{tabular}{cccccc}
\hline No. & $\begin{array}{c}\text { Excess of starch } \\
(\text { wt. } \%)\end{array}$ & $\begin{array}{c}\text { Holding time } \\
(\mathrm{h})\end{array}$ & $\begin{array}{c}\text { Weight before reaction } \\
(\mathrm{g})\end{array}$ & $\begin{array}{c}\text { Weight after reaction } \\
(\mathrm{g})\end{array}$ & $\begin{array}{c}\text { Mass loss } \\
(\%)\end{array}$ \\
\hline 1 & 5 & 1 & 2.0274 & 0.6514 & 67.9 \\
2 & 5 & 2 & 2.0101 & 0.4017 & 80.0 \\
3 & 5 & 3 & 2.0134 & 0.3499 & 82.6 \\
4 & 10 & 1 & 2.0427 & 0.6478 & 68.3 \\
5 & 10 & 2 & 2.0965 & 0.3886 & 81.5 \\
6 & 10 & 3 & 2.0256 & 0.3264 & 83.9 \\
7 & 15 & 1 & 2.0197 & 0.6368 & 68.5 \\
8 & 15 & 2 & 2.0357 & 0.3528 & 82.7 \\
9 & 15 & 3 & 2.0009 & 0.3163 & 84.2 \\
10 & 20 & 1 & 2.0238 & 0.6034 & 70.2 \\
11 & 20 & 2 & 2.0068 & 0.3279 & 83.7 \\
12 & 20 & 3 & 2.0114 & 0.2962 & 85.3 \\
\hline
\end{tabular}


the holding time is $3 \mathrm{~h}$, the whiskers and fine irregularly shaped particles in the synthesised product are greatly reduced, and short rod-shaped and almost flaky coarse particles form. As the holding time increases, the growth of whiskers is inhibited instead.

Figure 8 shows the SEM photographs of the precursor powder dried at $80{ }^{\circ} \mathrm{C}$ and the powder calcined

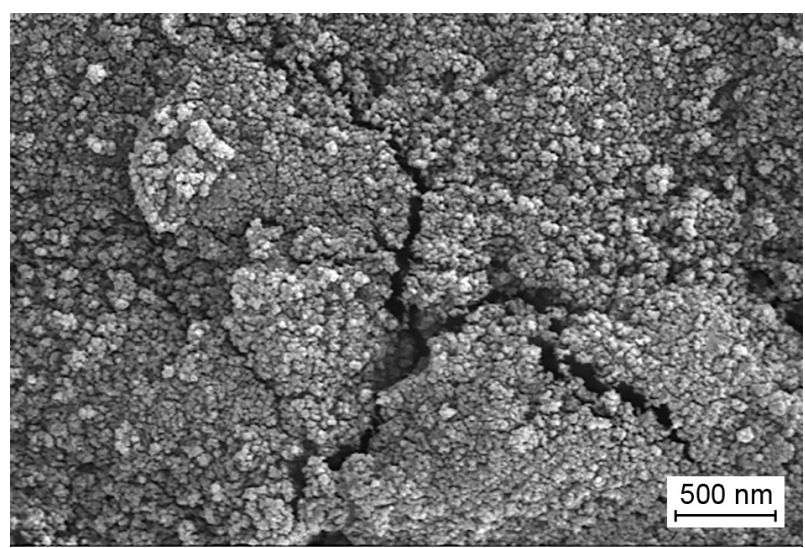

a) $80{ }^{\circ} \mathrm{C}+24 \mathrm{~h}$

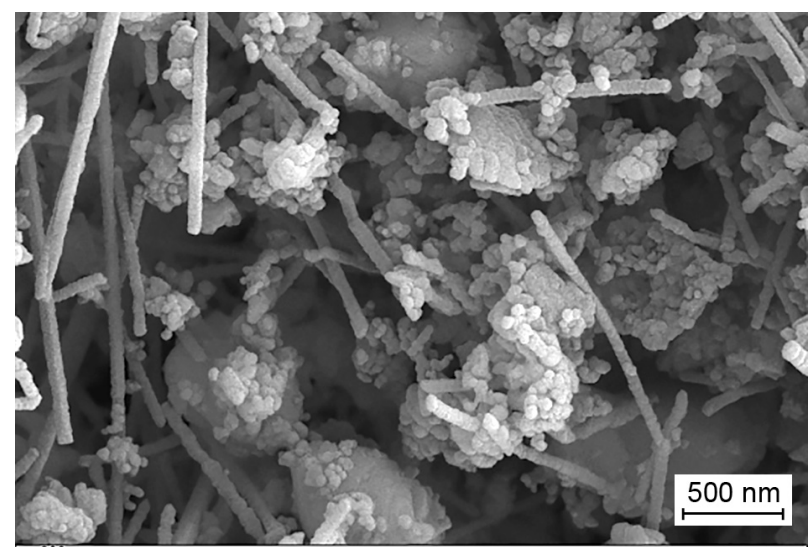

c) $1550{ }^{\circ} \mathrm{C}+2 \mathrm{~h}$ at $1550{ }^{\circ} \mathrm{C}$ for different durations with 20 wt. $\%$ excess of starch. The morphological characteristics in Figures $8 \mathrm{a}$ and $8 \mathrm{~b}$ are similar to those in Figure 7. The precursor powder samples dried at $80{ }^{\circ} \mathrm{C}$ are mainly composed of spherical and massive microstructures with $20 \mathrm{wt}$. \% excess of starch. The powder samples prepared at $1550{ }^{\circ} \mathrm{C}$ for $1 \mathrm{~h}$ are mainly composed of coarse flaky particles

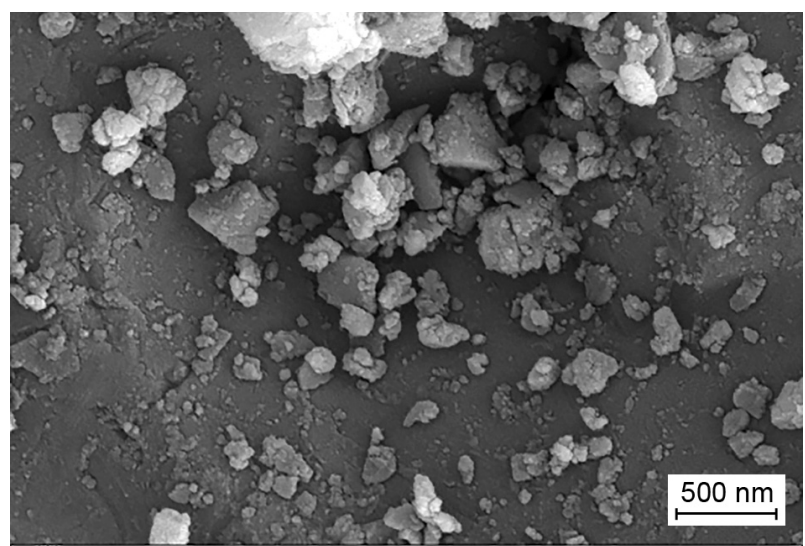

b) $1550{ }^{\circ} \mathrm{C}+1 \mathrm{~h}$

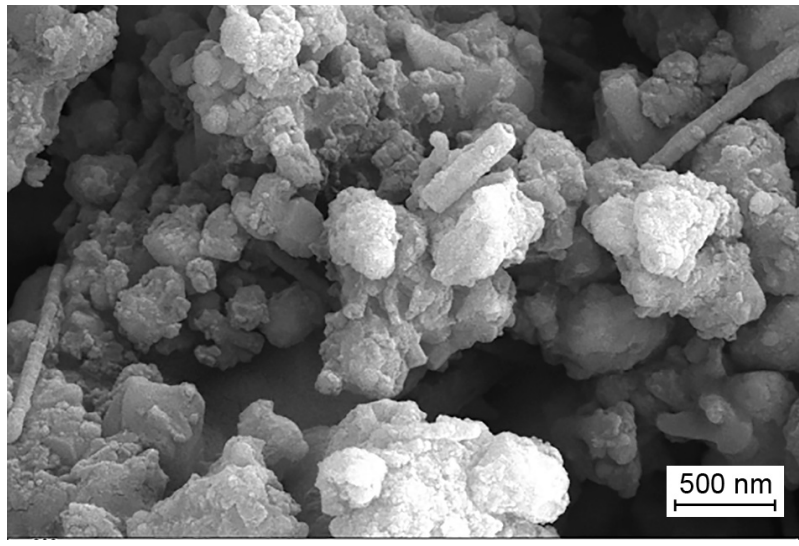

d) $1550{ }^{\circ} \mathrm{C}+3 \mathrm{~h}$

Figure 7. SEM photographs of the precursor powder dried at $80{ }^{\circ} \mathrm{C}$ and the powder calcined at $1550{ }^{\circ} \mathrm{C}$ for different durations with 10 wt. $\%$ excess of starch.

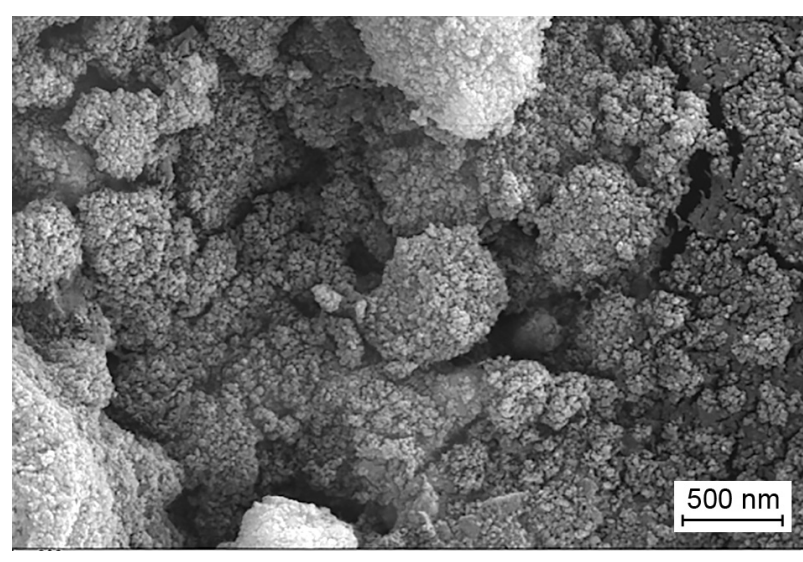

a) $80^{\circ} \mathrm{C}+24 \mathrm{~h}$

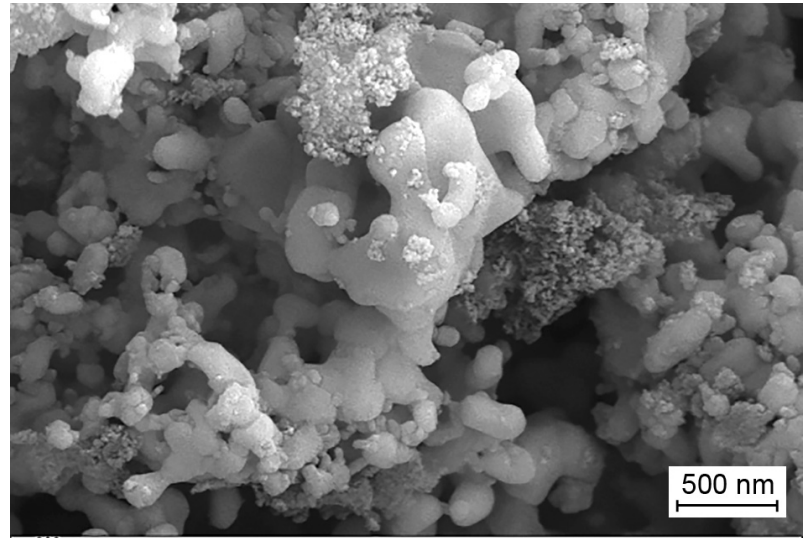

b) $1550{ }^{\circ} \mathrm{C}+1 \mathrm{~h}$

Figure 8. SEM photographs of the precursor powder dried at $80^{\circ} \mathrm{C}$ and the powder calcined at $1550{ }^{\circ} \mathrm{C}$ for different durations with 20 wt. \% excess of starch. (Continue on next page) 


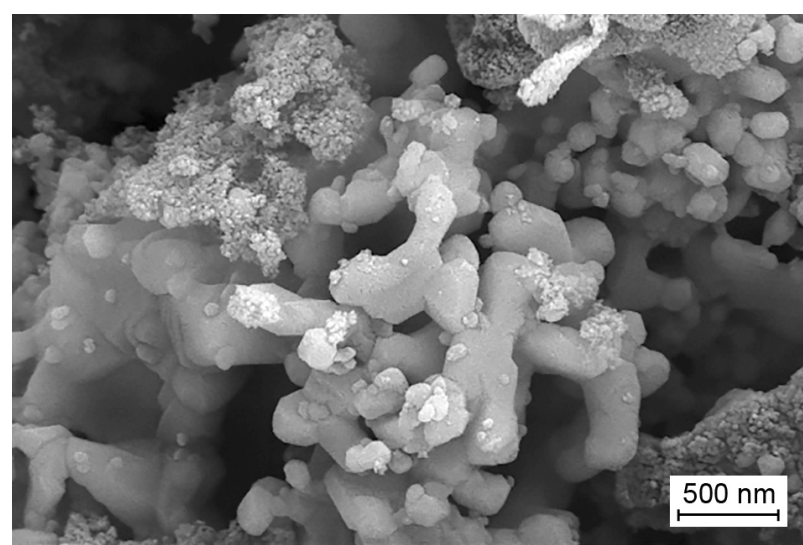

c) $1550{ }^{\circ} \mathrm{C}+2 \mathrm{~h}$

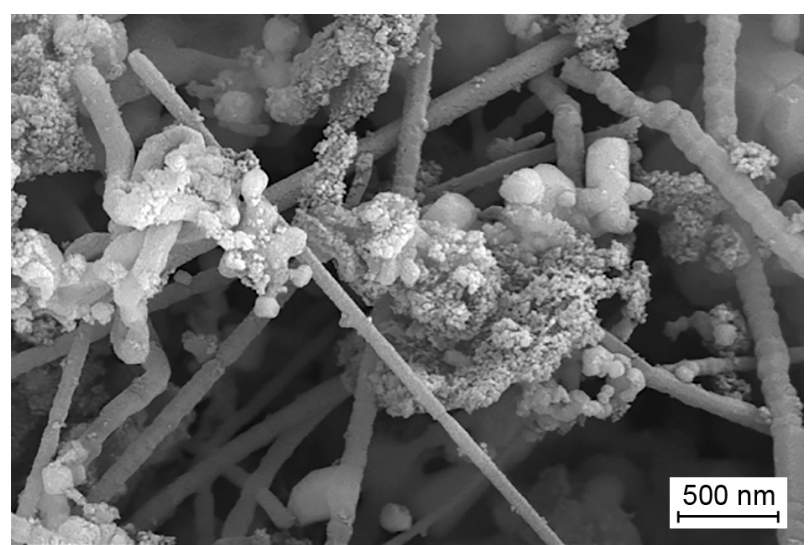

d) $1550{ }^{\circ} \mathrm{C}+3 \mathrm{~h}$

Figure 8. SEM photographs of the precursor powder dried at $80{ }^{\circ} \mathrm{C}$ and the powder calcined at $1550{ }^{\circ} \mathrm{C}$ for different durations with 20 wt. $\%$ excess of starch.

and small irregularly shaped particles. Agglomeration or adhesion exists between the powder particles, as shown in Figure 8b. When the powder samples are kept at $1550{ }^{\circ} \mathrm{C}$ for $2 \mathrm{~h}$, their morphological characteristics do not change significantly, as shown in Figure 8c. When the synthesised product is kept at $1550{ }^{\circ} \mathrm{C}$ for $3 \mathrm{~h}$, its morphological characteristics change greatly. The prepared powder samples are mainly composed of flake particles, irregularly shaped particles, and many thin and long whiskers (about $100-200 \mathrm{~nm}$ in diameter) with different thicknesses. A certain amount of overlap and entanglement occur between the whiskers, as shown in Figure 8d.

Figure 9 shows the SEM photographs of the powder samples calcined at $1550{ }^{\circ} \mathrm{C}$ for $2 \mathrm{~h}$ with $5 \mathrm{wt}$. \%, 10 wt. $\%, 15$ wt. $\%$, and 20 wt. $\%$ excess of starch, re-
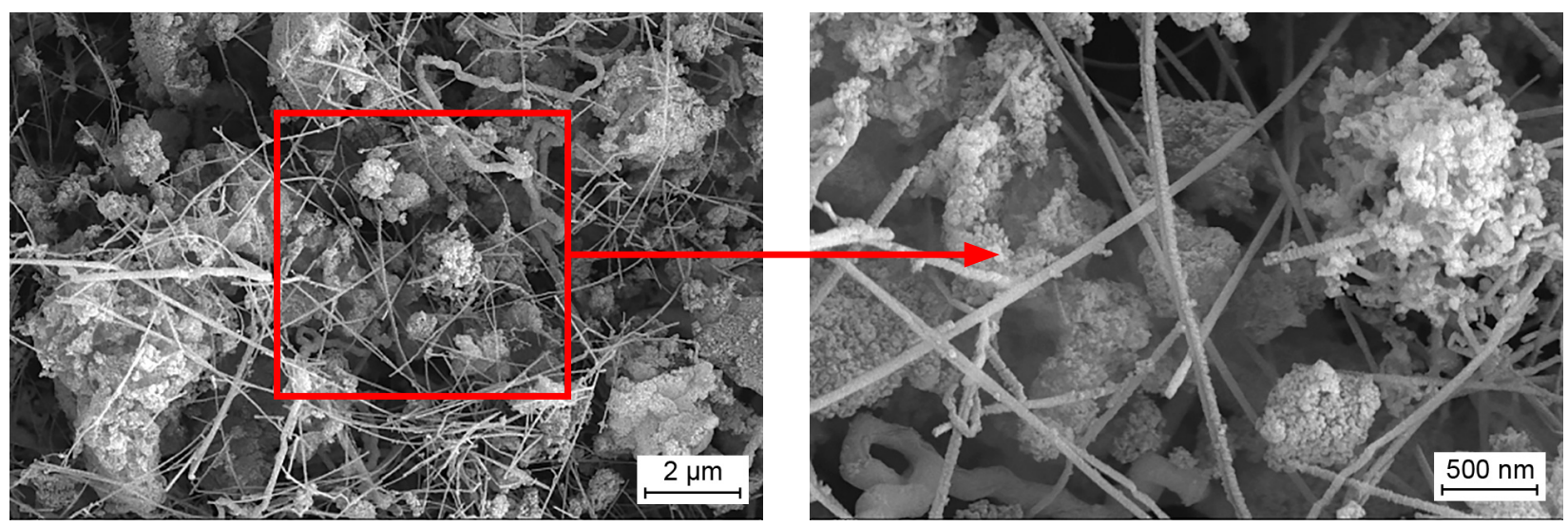

a) 5 wt. $\%$

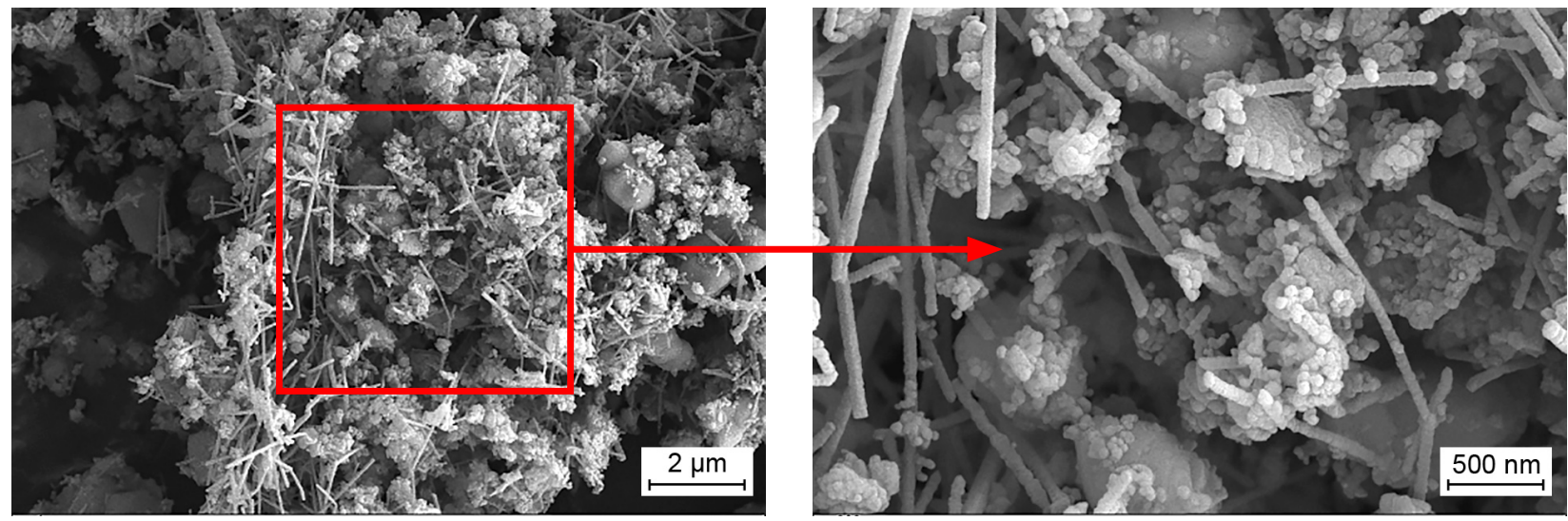

b) 10 wt. $\%$

Figure 9. SEM photographs of powder samples calcined at $1550{ }^{\circ} \mathrm{C}$ for $2 \mathrm{~h}$ with: a) $5 \mathrm{wt}$ \%, b) 10 wt. $\%$ excess of starch. (Continue on next page) 


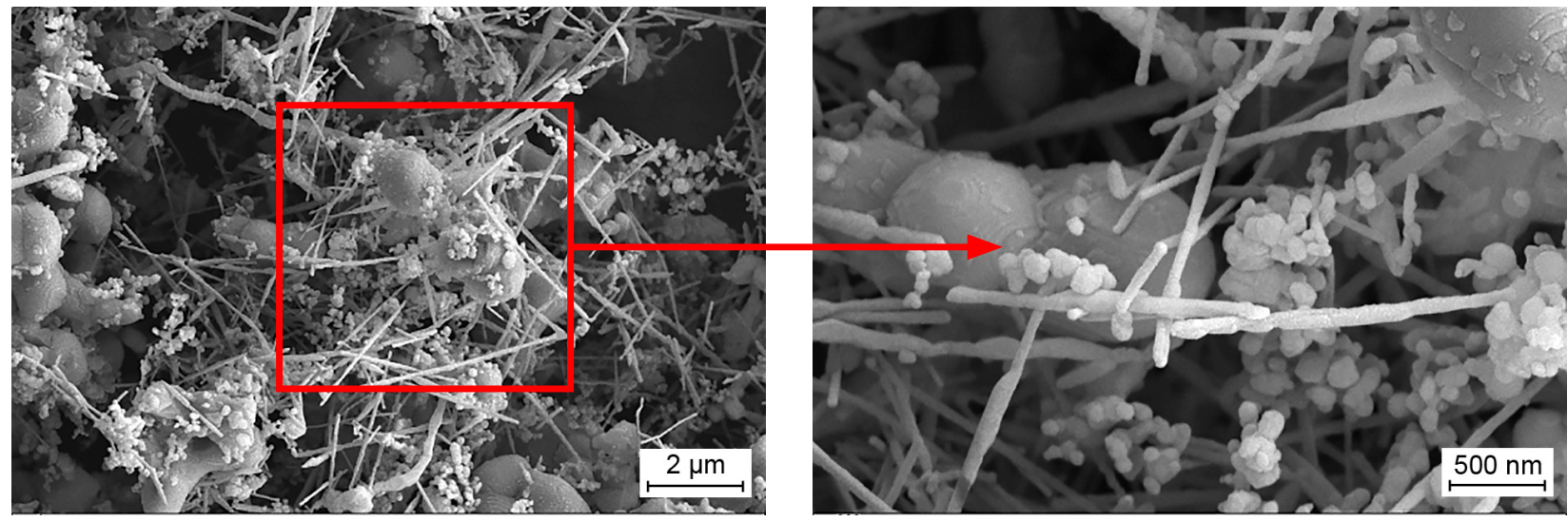

c) 15 wt. $\%$

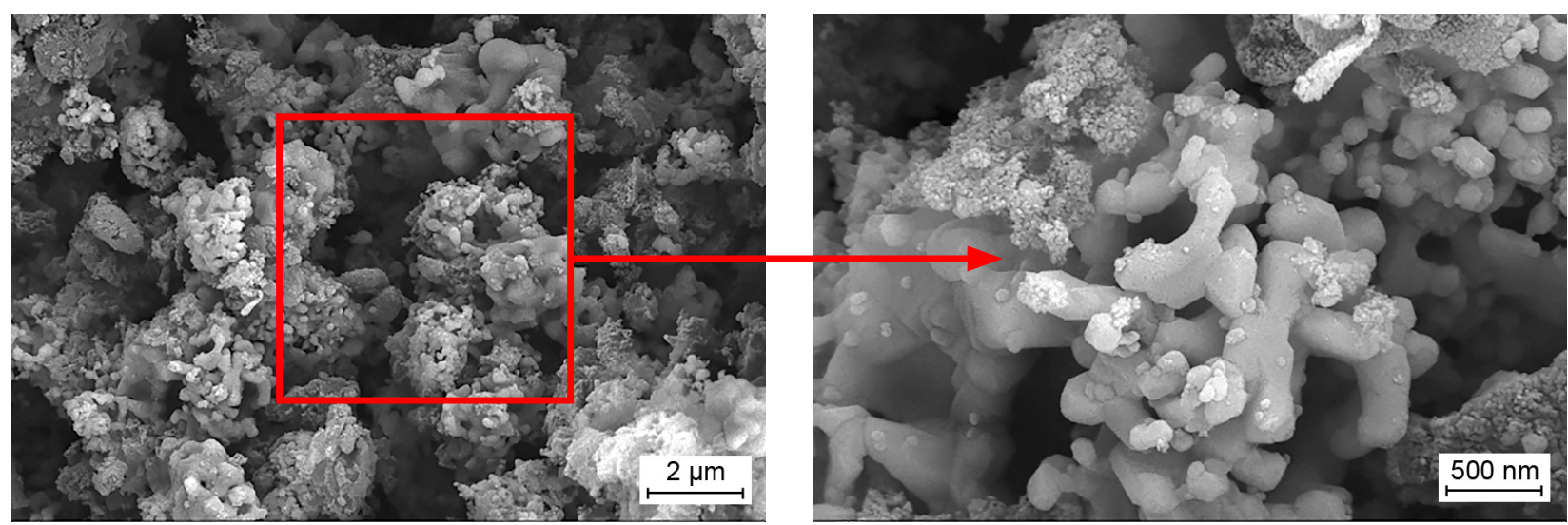

d) $20 \mathrm{wt} . \%$

Figure 9. SEM photographs of powder samples calcined at $1550^{\circ} \mathrm{C}$ for $2 \mathrm{~h}$ with: c) $15 \mathrm{wt} \%$, d) $20 \mathrm{wt} . \%$ excess of starch.

spectively. In comparison with the findings in Figures 9a to $9 \mathrm{c}$, the morphological characteristics of these powder samples with 5 - 15 wt. \% excess of starch calcined at $1550{ }^{\circ} \mathrm{C}$ for $2 \mathrm{~h}$ are mainly composed of flake particles, almost spherical particles, irregularly shaped particles and elongated whiskers, thereby forming a diversified microstructure. However, the morphological characteristics of the powder samples calcined at $1550{ }^{\circ} \mathrm{C}$ for $2 \mathrm{~h}$ mainly changed when the amount of excess starch is 20 wt. \%. The powder samples are mainly composed of flaky coarse particles and approximately spherical fine particles, as shown in Figure 9d.

\section{Energy spectrum analysis}

Figure 10 shows the SEM photographs and the EDS analysis results of the powder samples containing $20 \mathrm{wt} . \%$ excess of starch synthesised at $1550^{\circ} \mathrm{C}$ for $3 \mathrm{~h}$. The synthesised product mainly contains three elements, namely, $\mathrm{C}, \mathrm{Si}$, and $\mathrm{Ti}$, indicating that the $\mathrm{SiC}-\mathrm{TiC}$ composite powders are successfully synthesised in the system under this reaction condition. $\mathrm{SiC}$ whiskers are formed via two main mechanisms: gas-liquid-solid (VLS) and gas-solid (VS). In a carbothermal reduction without additives, the formation of $\mathrm{SiC}$ whiskers mainly follows the VS mechanism [19]. In the present study, the $\mathrm{SiO}_{2}$ in the precursor reacts with $\mathrm{C}$ from the starch decomposition at high temperatures to produce $\mathrm{SiO}$ and $\mathrm{CO}$; some $\mathrm{SiO}$ and $\mathrm{C}$ undergo a gas-solid reaction to form $\mathrm{SiC}$ particles, and the remaining parts of the $\mathrm{SiO}$ and $\mathrm{CO}$ undergo a gas-gas reaction to form the crystal nucleus of the $\mathrm{SiC}$; under suitable conditions, the crystal nucleus of the $\mathrm{SiC}$ seeks to grow along a specific direction to prepare $\mathrm{SiC}$ whiskers [20].

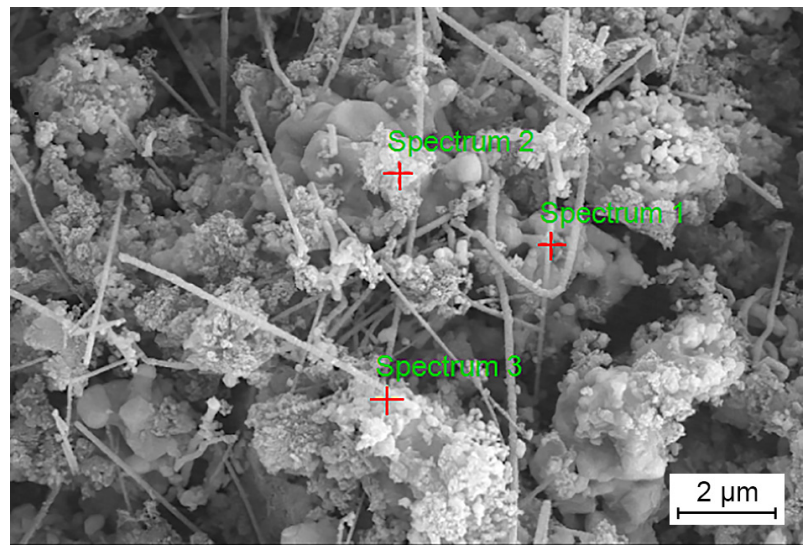

a) SEM photograph

Figure 10. SEM photograph and EDS analysis result of the powder samples with $20 \mathrm{wt}$. \% excess of starch synthesised at $1550{ }^{\circ} \mathrm{C}$ for $3 \mathrm{~h}$. (Continue on next page) 


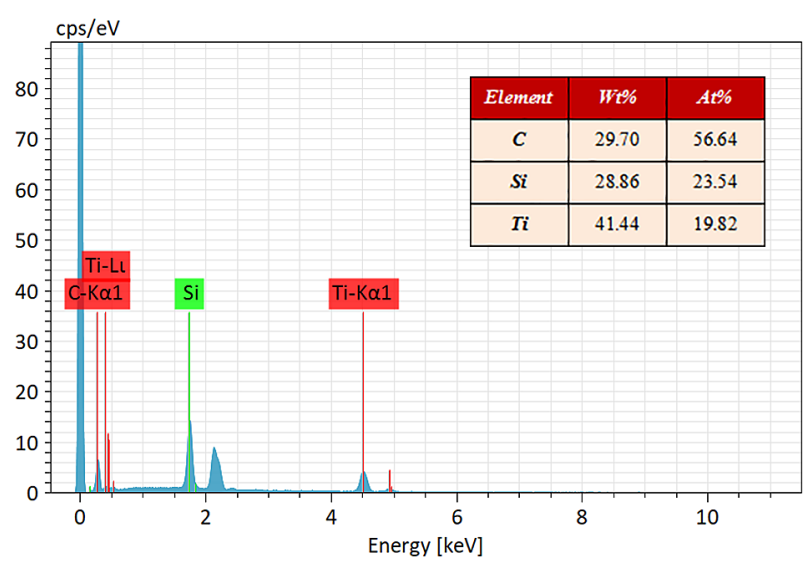

b) Spectrum 1

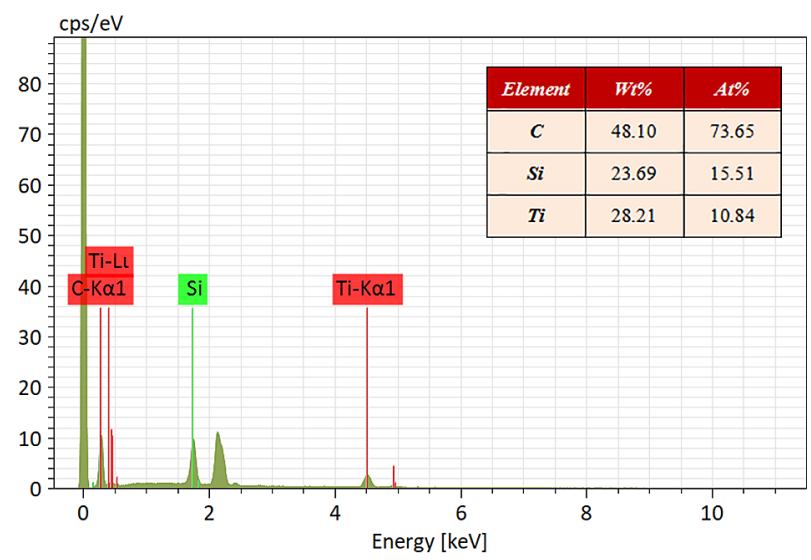

c) Spectrum 2

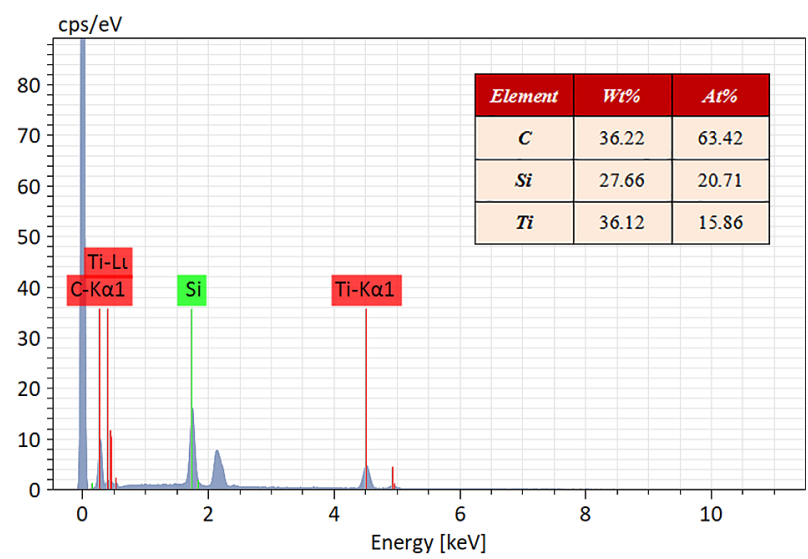

d) Spectrum 3

Figure 10. SEM photograph and EDS analysis result of the powder samples with $20 \mathrm{wt}$. \% excess of starch synthesised at $1550{ }^{\circ} \mathrm{C}$ for $3 \mathrm{~h}$.

\section{CONCLUSIONS}

Both $\mathrm{SiO}_{2}$ compounds in the silica sol as a raw material and the elemental carbon generated through the decomposition of the raw starch materials at high temperatures mainly exist in a system in their amorphous forms. SiC-TiC composite powders are completely synthesised after holding at $1550{ }^{\circ} \mathrm{C}$ for $3 \mathrm{~h}$ when the amount of excess starch is $5 \mathrm{wt}$ \%. Similarly, SiC-TiC composite powders are completely synthesised under the condition of holding at $1550{ }^{\circ} \mathrm{C}$ for $2 \mathrm{~h}$ when the amount of excess starch is $10-20 \mathrm{wt}$. \%. This finding is basically consistent with the analysis result of the mass loss during synthesis.

The morphological characteristics of the powder samples with 5 - 15 wt. \% excess of starch calcined at $1550{ }^{\circ} \mathrm{C}$ for $2 \mathrm{~h}$ mainly include flake particles, spherical particles, irregularly shaped particles and elongated whiskers, forming a diversified microstructure. In comparison, the powder samples calcined at $1550{ }^{\circ} \mathrm{C}$ for $2 \mathrm{~h}$ are mainly composed of flaky coarse particles and approximately spherical fine particles, but they hardly contain any whiskers.

\section{Acknowledgements}

This work is supported by the Key $R \&$ D Project in Hunan Province (Grant No. 2021GK2015), the Planned Science and Technology Program of Hunan Province, China (Grant No. 2016TP1028) and the Natural Science Foundation of Hunan Province, China (Grant No. 2016JJ6047).

\section{REFERENCES}

1. Xu T., Cheng S., Jin L., Zhang K., Zeng T. (2020): Hightemperature flexural strength of $\mathrm{SiC}$ ceramics prepared by additive manufacturing. International Journal of Applied Ceramic Technology, 17(2), 438-448. doi: 10.1111/ijac. 13454

2. Kim K.J., Lim K.Y., Kim Y.W. (2014): Electrical and thermal properties of $\mathrm{SiC}$ ceramics sintered with yttria and nitrides. Journal of the American Ceramic Society, 97(9), 2943-2949. doi: 10.1111/jace.13031

3. Cornolti L., Martinelli S., Bianchi G., Ortona A. (2019): Microwave heating controlled reactive melt infiltration for graphite-Si-SiC ceramics manufacturing. Journal of the American Ceramic Society, 102(5), 2304-2315. doi: 10. 1111/jace. 16124

4. Vajdi M., Moghanlou F.S., Nekahi S., Ahmadi Z., Asl M.S. (2020): Role of graphene nano-platelets on thermal conductivity and microstructure of $\mathrm{TiB}_{2}-\mathrm{SiC}$ ceramics. Ceramics International, 46(13), 21775-21783. doi: 10. 1016/j.ceramint.2020.05.289

5. Yao M., Wang Y., Chen L., Ouyang J., Li H., Gu H., Zhou Y. (2021): Mechanical properties and microstructural evolution of pressureless sintered ceramics obtained from highenergy ball-milled $\mathrm{TiB}_{2}-\mathrm{TiC}$ powders. Materials Science and Engineering A, 819(5), 141510-141519. doi: 10.1016/ j.msea.2021.141510

6. Wang X.C., Zhao J., Cui E.Z., Sun Z.F., Yu H. (2021): Grain growth kinetics and grain refinement mechanism in $\mathrm{Al}_{2} \mathrm{O}_{3} / \mathrm{WC} / \mathrm{TiC} /$ graphene ceramic composite. Journal of the European Ceramic Society, 41(2), 1391-1398. doi: 10. 1016/j.jeurceramsoc.2020.10.019

7. Ge D., Deng J., Duan R., Li X., Yue H. (2019): Effect of surface wettability on tribological properties of $\mathrm{Al}_{2} \mathrm{O}_{3} / \mathrm{TiC}$ 
ceramic under wet lubrication. Ceramics International, 45(18), 24554-24563. doi: 10.1016/j.ceramint.2019.08.184

8. Asl M.S., Ahmadi Z., Namini A.S., Babapoor A., Motallebzadeh A. (2019): Spark plasma sintering of $\mathrm{TiC}_{-} \mathrm{SiC}_{\mathrm{w}}$ ceramics. Ceramics International, 45(16), 19808-19821. doi: 10.1016/j.ceramint.2019.06.236

9. Wang F., Xiang D., Wang Y., Li J. (2017): Rapid synthesis of SiC powders by spark plasma-assisted carbothermal reduction reaction. Ceramics International, 43(6), 4970-4975. doi: 10.1016/j.ceramint.2017.01.003

10. Chen X., Fan J., Lu Q. (2018): Synthesis and characterization of TiC nanopowders via sol-gel and subsequent carbothermal reduction process. Journal of Solid State Chemistry, 262, 44-52. doi: 10.1016/j.jssc.2018.03.006

11. Oghenevweta E.J., Wexler D., Calka A. (2016): Early stages of phase formation before the ignition peak during mechanically induced self-propagating reactions (MSRs) of titanium and graphite. Scripta Materialia, 122, 93-97. doi: 10.1016/j.scriptamat.2016.05.028

12. Song M., Yang Y., Xiang M., Zhu Q., Zhao H. (2020): Synthesis of nano-sized TiC powders by designing chemical vapor deposition system in a fluidized bed reactor. Powder Technology, 380, 256-264. doi: 10.1016/j.powtec. 2020.11.045

13. Su X., Zhou W., Jie X., Wang J., He X., Chong F., Li Z. (2012): Preparation and dielectric property of $\mathrm{Al}$ and $\mathrm{N}$ Co-doped $\mathrm{SiC}$ powder by combustion synthesis. Journal of the American Ceramic Society, 95(4), 1388-1393. doi: 10.1111/j.1551-2916.2011.04996.x

14. Hu J.L., Xiao H.N., Li Q., Guo W.M., Gao P.Z. (2011): Synthesis and growth mechanism of $\mathrm{TiC}-\mathrm{SiC}$ composite powders by carbothermal reduction. The Chinese Journal of Nonferrous Metals, 21(5), 1131-1136. doi: 10.3354/ cr00999

15. Hu J.L., Peng H.X., Hu C.Y., Guo W.M., Tian X.Y., Peng Y.X. (2017): Effects of different carbon sources and reaction temperatures on the synthesis of $\mathrm{SiC}-\mathrm{TiC}$ composite powders by carbothermal reduction. Journal of Ceramic Processing Research, 18(1), 79-85.

16. Sun H.Y., Kong X., Sen W., Liu G.Y., Yi Z.Z. (2015): Synthesis and characterization of TiC powders by carbothermal reduction method in vacuum. Advanced Materials Research, 1089(1), 147-151. doi:10.4028/www.scientific. net/AMR.1089.147

17. Hu J.L., Hu C.Y., Guo W.M., Wang X.C., Tian X.Y., Peng Y.X. (2017): Synthesis of SiC-TiC composite powders using glucose as carbon source. Journal of Synthetic Crystals, 46(2), 311-315.

18. Sharma N.K., Williams W.S., Zangvil A. (1984): Formation and structure of silicon carbide whiskers from rice hulls. Journal of the American Ceramic Society, 67(11), 715-720. doi: 10.1111/j.1151-2916.1984.tb19507.x 